\title{
A SIMPLE MODEL TO FIT THE TIME EVOLUTION OF THE DAILY DEATH RATE OF COVID-19 IN EUROPEAN UNION COUNTRIES
}

\author{
Tristan Beau ${ }^{1}$, Julien Browaeys ${ }^{2}$, Olivier Dadoun ${ }^{1}$ \\ 1 : Laboratoire de Physique Nucl?aire et des Hautes ?nergies, CNRS UMR 7585, Sorbonne Universit?, Universit? de Paris, CNRS/IN2P3, 4 place Jussieu, 75005 Paris, France. ${ }^{2}$ \\ : Laboratoire Mati?re et Syst?mes Complexes, CNRS UMR 7057, Universit? de Paris, 10 rue Alice Domon et L?onie Duquet, 75013 Paris, France
}

\begin{abstract}
We suggest a minimal model to describe the evolution of daily deaths due to Covid-19 in the European Union (EU) and UK, without any epidemiological hypothesis. Assuming current lockdown conditions were to remain in place, as of May 3rd 2020, this ad hoc fitting model is forecasting a total of 204586 deaths in the EU. We could currently be at $2 / 3$ of the total casualty count, and reach an overall death rate of one over 2500 people.
\end{abstract}

\section{I. - Introduction}

The current Covid-19 pandemia is a major worldwide concern since its outbreak in December 2019[1]. Although all countries are publishing their statistics in term of deaths, confirmed or recovered cases, the epidemiological modeling remains complex. In this study, we propose an modelization of data without any epidemiological assumptions.

The realization of a major epidemic crisis happening in the European Union (EU) came in March 2020, and most EU countries consequently instituted some form of lockdown in a matter of days. Since then, at least in Europe, the epidemics has receded enough so that these countries have planned to lift the lockdown, at least partially, in the second week of May.

We wish to contribute to the evaluation of the incidence of such a decision based on current data. We fit an effective physical model to public Covid-19 deaths data in all 28 EU countries (including UK) in order to forecast the evolution of the epidemic if lockdown was maintained. In that case, the total number of deaths is estimated.

\section{II. - Data and method}

The John Hopkins University database[5] provides a daily report of deaths, confirmed and recovered Covid-19 patients all over the world, since January 22nd, 2020; this date is considered to be our time reference $t=0$. Because of large variations in testing policies in different countries, in this analysis we limit ourselves to the study of daily deaths as a function of time. We are aware that this remains an imperfect proxy of the epidemic as counting policies can also vary from one country to the other.

In order to be able to compare countries, we normalize data by country population. This information is taken from the latest United Nations Population Division estimates [4]. Databases extraction of data and their initial analysis is ensured by the open source software called CoCoA $[2$, 3].

\section{III. - Analysis and extrapolation}

The effective modeling of data is done by a standard least-square fit of a Crystal Ball function [6].

$f\left(t ; \alpha, n, t_{0}, \sigma\right) \propto \begin{cases}\exp \left(-\frac{\left(t-t_{0}\right)^{2}}{2 \sigma^{2}}\right), & \text { for } \frac{t-t_{0}}{\sigma}>-\alpha\end{cases}$

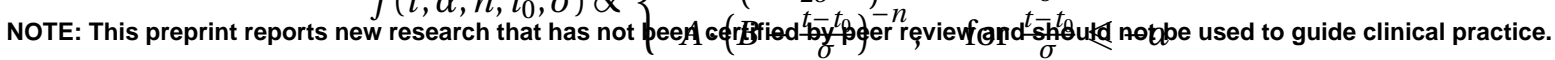


medRxiv preprint doi: https://doi.org/10.1101/2020.05.06.20093062; this version posted May 10, 2020. The copyright holder for this preprint (which was not certified by peer review) is the author/funder, who has granted medRxiv a license to display the preprint in perpetuity.

It is made available under a CC-BY 4.0 International license .

The Crystal Ball function consists of a smoothly joined Gaussian part and a power-law tail at a certain cut-off. It has 5 parameters : $N$ is the full integral of the function over the time, $n$ the power law parameter, $\alpha$ a normalized cutoff where the power-law replaces the Gaussian part, $t_{0}$ the position of the peak, $\sigma$ the time scale. We are only reporting the useful parameters $N$ and $t_{0}$, which respectively describe the total number of death (assuming the daily death rate to follow this function) and the time at which the peak of the epidemic occurred.

Commonly used in high-energy physics, this function is named after a neutral particle detector initially used at the Stanford Linear Accelerator Center. The reason for choosing this function is two-fold. First we needed to describe properly the asymmetrical bell shape curve of the data (see figures below). Second we wanted a minimum number of adjustable parameters to avoid over-fitting.

For every EU countries (and UK), we represent daily deaths as a function of time since $t=0$, together with the fitted Crystal Ball function. It is represented over 200 days to better visualize our forecast. The best fit parameters $N$ and $t_{0}$ are given on each figure.
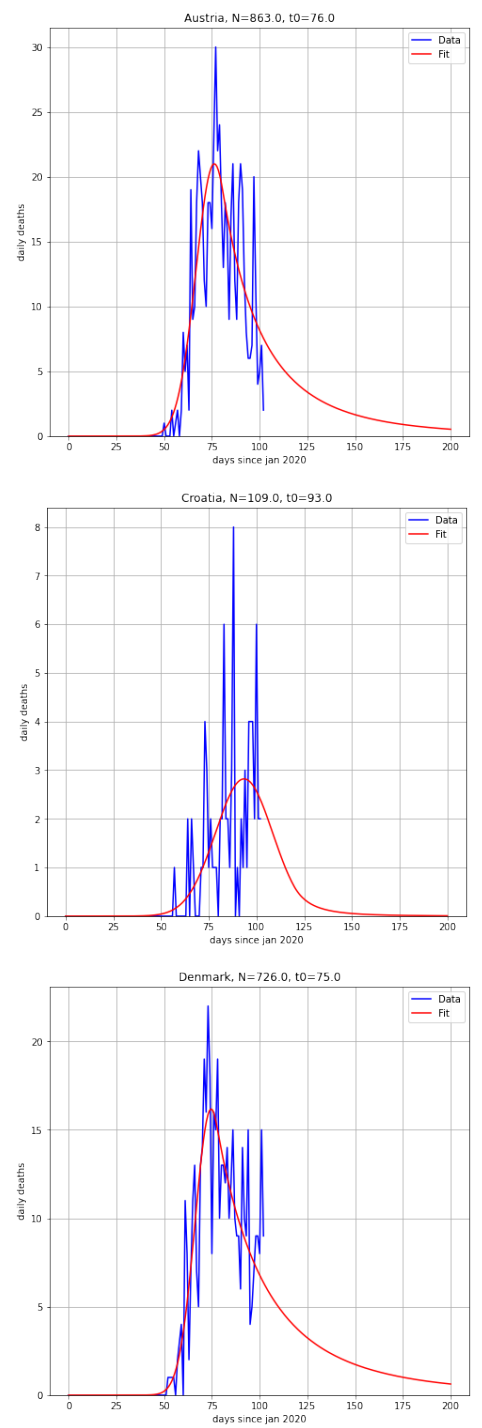
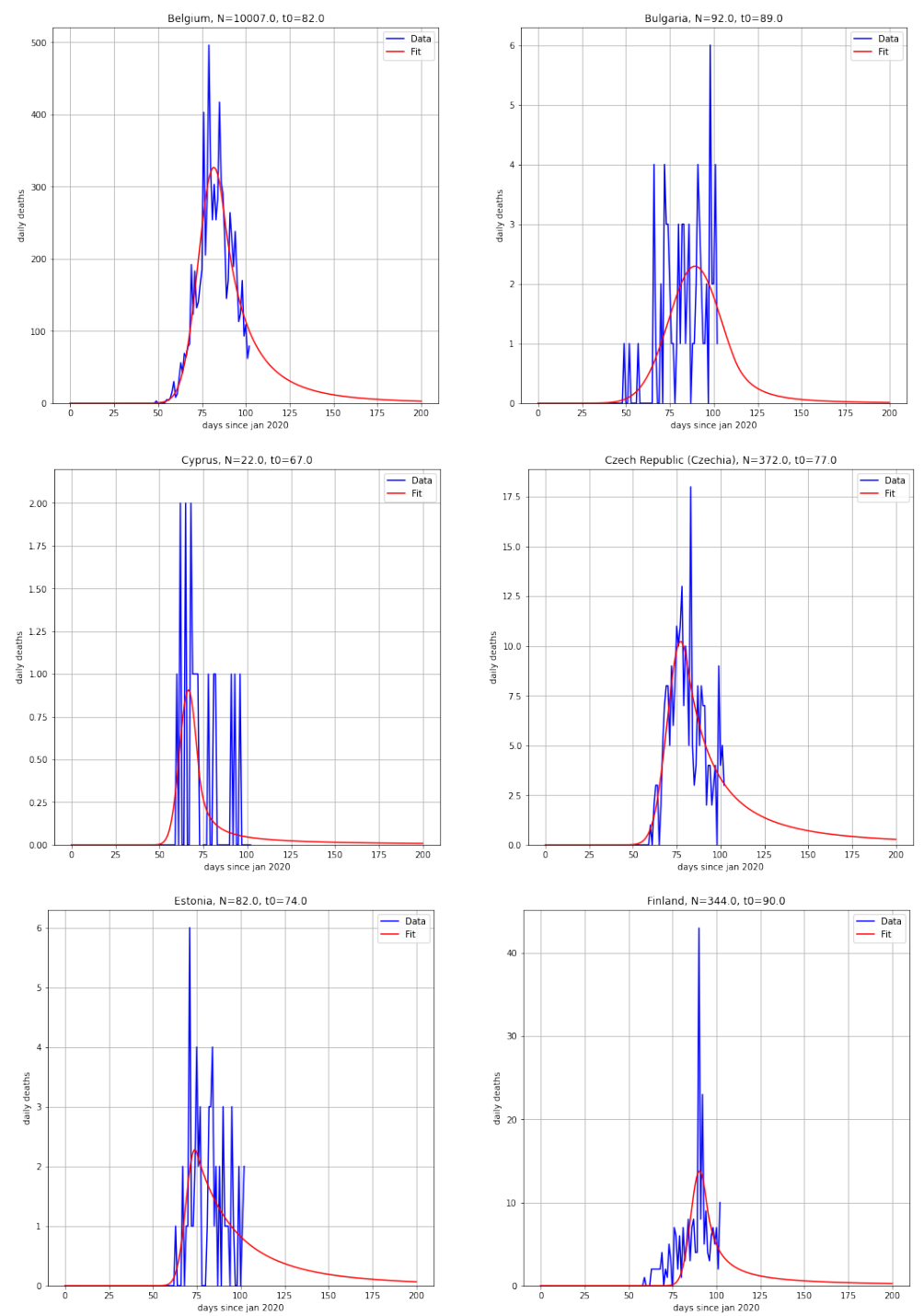
medRxiv preprint doi: https://doi.org/10.1101/2020.05.06.20093062; this version posted May 10, 2020. The copyright holder for this preprint (which was not certified by peer review) is the author/funder, who has granted medRxiv a license to display the preprint in perpetuity.

It is made available under a CC-BY 4.0 International license .
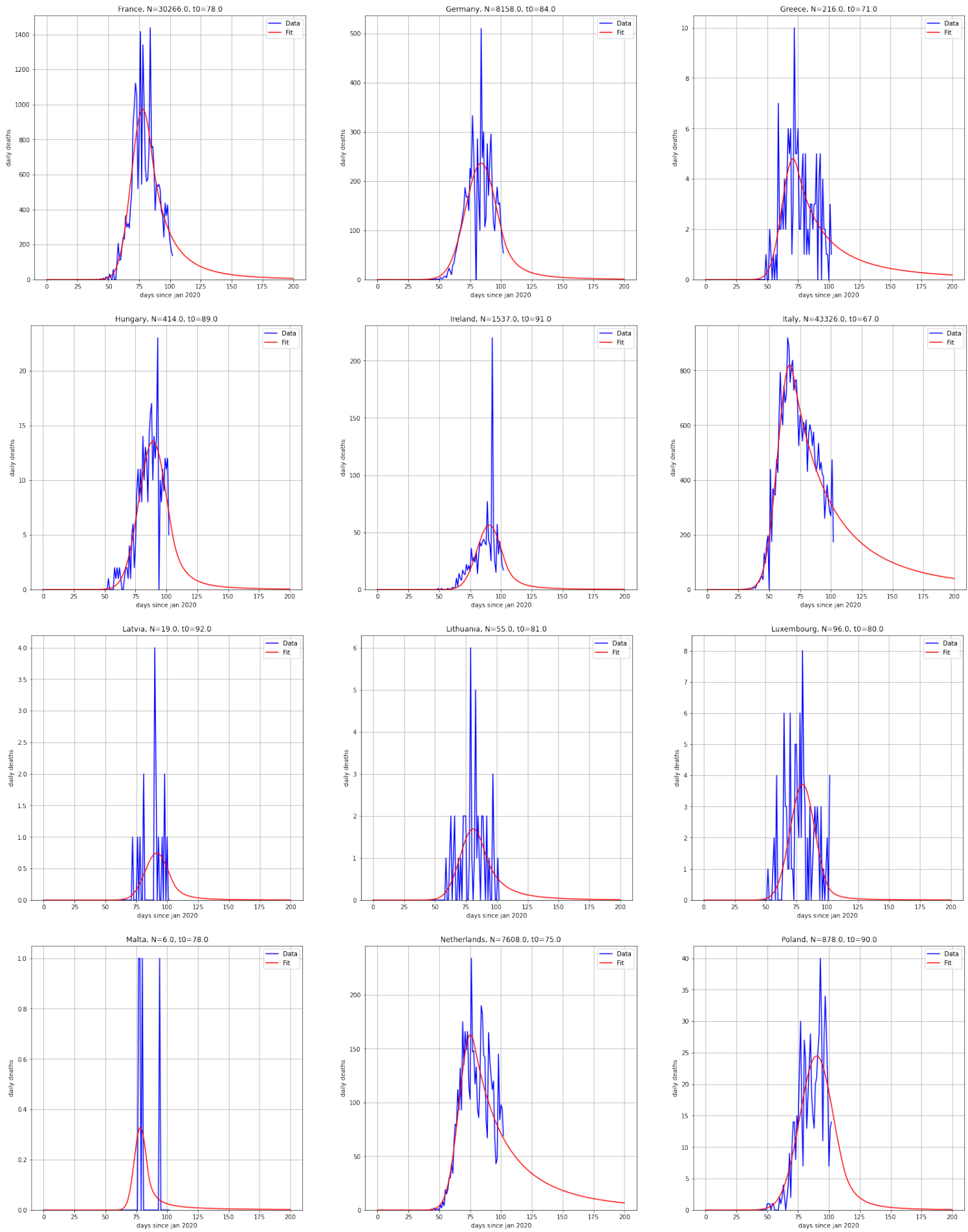
medRxiv preprint doi: https://doi.org/10.1101/2020.05.06.20093062; this version posted May 10, 2020. The copyright holder for this preprint (which was not certified by peer review) is the author/funder, who has granted medRxiv a license to display the preprint in perpetuity.

It is made available under a CC-BY 4.0 International license .
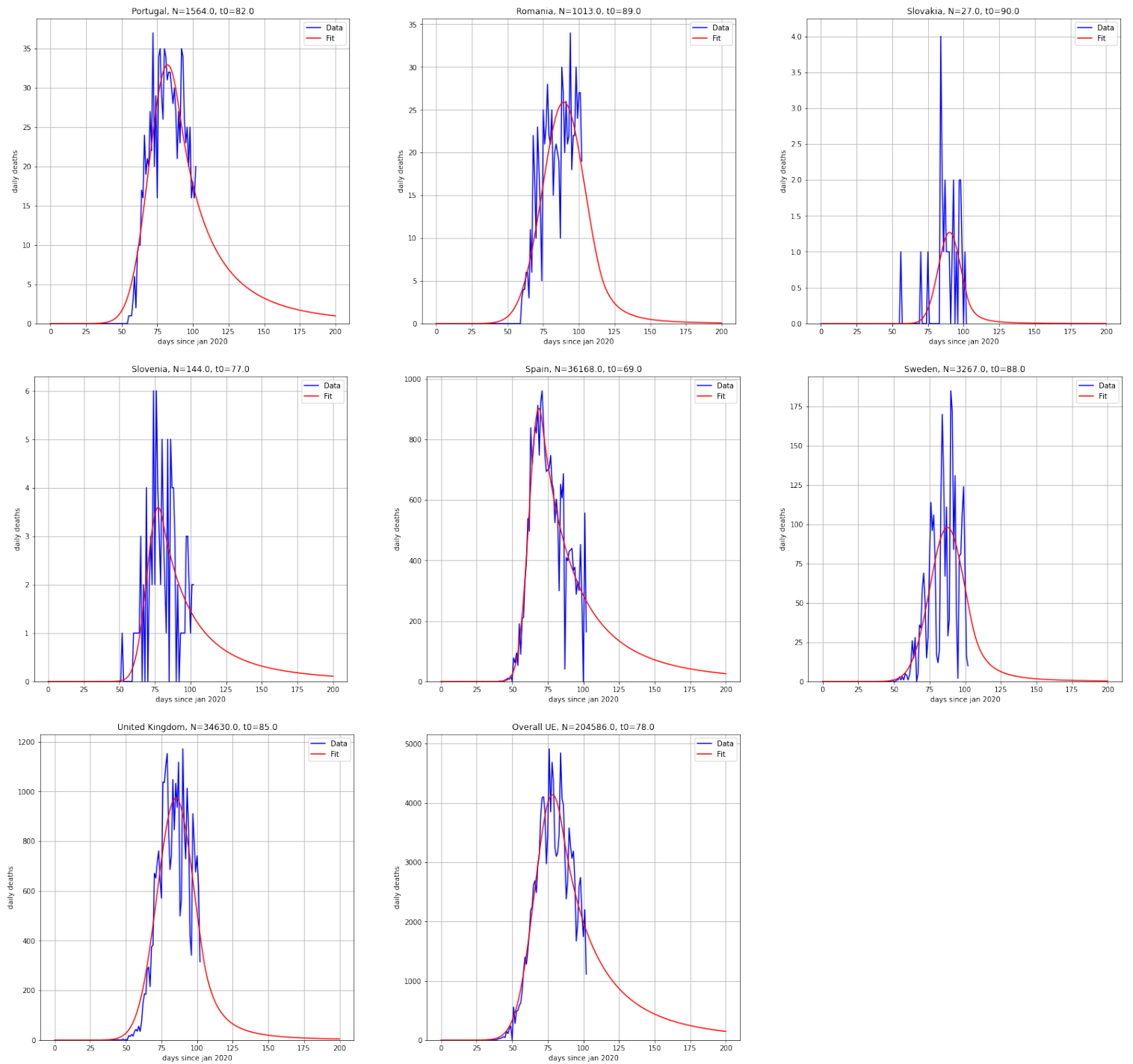

The same procedure has also been applied to European Union (including UK) as a whole.

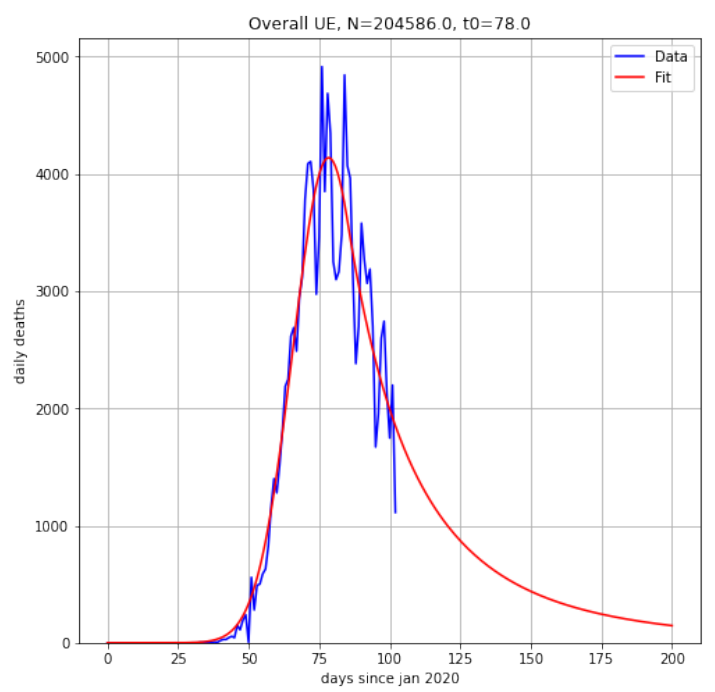




\section{IV. - Discussion}

Our modeling yields an estimation of the expected overall number of deaths for each country. We provide these numbers in the table below, and compare them with the total number deaths reported until May 3rd, 2020, to infer the progress of the epidemic at this date. We normalize the figures by population to facilitate comparison between countries.

\begin{tabular}{|c|c|c|c|c|c|c|c|}
\hline Country & Population & $\begin{array}{r}\text { Deaths } \\
\text { (May } \\
\text { 3rd) }\end{array}$ & $\begin{array}{r}\text { Total } \\
\text { forecast } \\
N\end{array}$ & $\begin{array}{c}\text { Peak } \\
\text { date } t_{0}\end{array}$ & $\begin{array}{r}\text { Deaths } \\
\text { (May } \\
\text { 3rd) per } \\
\text { 100k pop }\end{array}$ & $\begin{array}{r}\text { Total } \\
\text { forecast } \\
\text { per } 100 \mathrm{k} \\
\text { pop }\end{array}$ & $\begin{array}{r}\text { Extent } \\
\text { (May } \\
\text { 3rd) in \% }\end{array}$ \\
\hline $\mathrm{UE}+\mathrm{UK}$ & 513136525 & 137796 & 204586 & 78 & 26.9 & 39.9 & 67.4 \\
\hline Germany & 83783942 & 6993 & 8158 & 84 & 8.3 & 9.7 & 85.7 \\
\hline United Kingdom & 67886011 & 28809 & 34630 & 85 & 42.4 & 51.0 & 83.2 \\
\hline France & 65273511 & 25204 & 30266 & 78 & 38.6 & 46.4 & 83.3 \\
\hline Italy & 60461826 & 29079 & 43326 & 67 & 48.1 & 71.7 & 67.1 \\
\hline Spain & 46754778 & 25428 & 36168 & 69 & 54.4 & 77.4 & 70.3 \\
\hline Poland & 37846611 & 698 & 878 & 90 & 1.8 & 2.3 & 79.5 \\
\hline Romania & 19237691 & 818 & 1013 & 89 & 4.3 & 5.3 & 80.8 \\
\hline Netherlands & 17134872 & 5098 & 7608 & 75 & 29.8 & 44.4 & 67.0 \\
\hline Belgium & 11589623 & 7924 & 10007 & 82 & 68.4 & 86.3 & 79.2 \\
\hline Czech Rep. & 10708981 & 252 & 372 & 77 & 2.4 & 3.5 & 67.7 \\
\hline Greece & 10423054 & 146 & 216 & 71 & 1.4 & 2.1 & 67.6 \\
\hline Portugal & 10196709 & 1063 & 1564 & 82 & 10.4 & 15.3 & 68.0 \\
\hline Sweden & 10099265 & 2769 & 3267 & 88 & 27.4 & 32.3 & 84.8 \\
\hline Hungary & 9660351 & 351 & 414 & 89 & 3.6 & 4.3 & 84.8 \\
\hline Austria & 9006398 & 600 & 863 & 76 & 6.7 & 9.6 & 69.5 \\
\hline Bulgaria & 6948445 & 78 & 92 & 89 & 1.1 & 1.3 & 84.8 \\
\hline Denmark & 5792202 & 493 & 726 & 75 & 8.5 & 12.5 & 67.9 \\
\hline Finland & 5540720 & 240 & 344 & 90 & 4.3 & 6.2 & 69.8 \\
\hline Slovakia & 5459642 & 25 & 27 & 90 & 0.5 & 0.5 & 92.6 \\
\hline Ireland & 4937786 & 1319 & 1537 & 91 & 26.7 & 31.1 & 85.8 \\
\hline Croatia & 4105267 & 80 & 109 & 93 & 1.9 & 2.7 & 73.4 \\
\hline Lithuania & 2722289 & 46 & 55 & 81 & 1.7 & 2.0 & 83.6 \\
\hline Slovenia & 2078938 & 97 & 144 & 77 & 4.7 & 6.9 & 67.4 \\
\hline Latvia & 1886198 & 16 & 19 & 92 & 0.8 & 1.0 & 84.2 \\
\hline Estonia & 1326535 & 55 & 82 & 74 & 4.1 & 6.2 & 67.1 \\
\hline Cyprus & 1207359 & 15 & 22 & 67 & 1.2 & 1.8 & 68.2 \\
\hline Luxembourg & 625978 & 96 & 96 & 80 & 15.3 & 15.3 & 100.0 \\
\hline Malta & 441543 & 4 & 6 & 78 & 0.9 & 1.4 & 66.7 \\
\hline
\end{tabular}

With merely five free parameters, our model fits reasonably well all data for the $28 \mathrm{EU}$ countries (and UK). Fitting seems all the more accurate that the peak can be easily identified, and that the total number of daily death is high.

Some countries plan lifting the lockdown in early May 2020, such as Germany (May 4th), or France (May 11th). One can assume that without lifting the lockdown, the evolution of the daily rate of death could have followed the trend we have exhibited.

On May 3rd, EU countries (and UK) have recorded a total of 136391 deaths due to Covid19. Our effective model is projecting 204586 deaths if all conditions remain as current. In 
medRxiv preprint doi: https://doi.org/10.1101/2020.05.06.20093062; this version posted May 10, 2020. The copyright holder for this preprint (which was not certified by peer review) is the author/funder, who has granted medRxiv a license to display the preprint in perpetuity.

It is made available under a CC-BY 4.0 International license .

this hypothesis, $2 / 3$ of the total number of Covid-19 victims have already perished. It will be interesting to compare these figures with the total number of death at the end of the epidemic.

We should stress that our proposal is prospective and not predictive, in the sense that it does not rely on epidemiological modeling. We merely describe data through ad hoc fitting of mathematical functions, a methodology similar to what is used in economic forecasts.

\section{V. - Conclusion}

We provide an minimal model, within the CoCoA framework, that reasonably fits the daily rate of death as a function of time with only five free parameters. Assuming lockdown is not lifted, we estimate that at the beginning of May 2020 about two third of deaths have already occurred in Europe before the end of the epidemic. This implies a final total death rate of 1 over 2500 people. In the future, lockdown lifting policies could be evaluated with regard to our projection.

\section{References}

[1] "About the Virus." World Health Organization, May 4, 2020. http://www.euro. who.int/en/health-topics/health-emergencies/coronavirus-covid-19/ novel-coronavirus-2019-ncov,

[2] Tristan Beau, Julien Browaeys, Olivier Dadoun. CoCoA, a free Collaborative Covid Analysis tool. Preprint under preparation.

[3] Tristan Beau, Olivier Dadoun, Julien Browaeys. GitHub CoCoA Official Repository (version 0.1). Python, 2020. https://github.com/tjbtjbtjb/CoCoA.

[4] "Population by Country (2020) - Worldometer." Accessed May 4, 2020. https://www . worldometers.info/world-population/population-by-country/.

[5] CSSEGISandData/COVID-19 by the Center for Systems Science and Engineering (CSSE) at Johns Hopkins University, 2020. https ://github.com/CSSEGISandData/COVID-19.

[6] Skwarnicki, T. A study of the radiative CASCADE transitions between the Upsilon-Prime and Upsilon resonances. (PhD Thesis, Cracow, INP, 1986). https://inspirehep.net/literature/230779 